\title{
Carbon footprint of pre-fabricated wood buildings
}

\author{
Alejandro Padilla-Rivera, ${ }^{1, a}$, Pierre Balnchet ${ }^{1}$ \\ ${ }^{1}$ Université Laval-CIRCERB, Faculté des sciences de bois. Pavillon Gene-H.-Kruger Université Laval 2348, rue de la Terrasse Québec \\ (Québec) G1V OA6, Québec, Canada. +1 418 656-2131 ext. 16292.
}

\begin{abstract}
.
This study reports on a study examining the potential of reducing greenhouse gas (GHG) emissions from the building sector by substituting steel and concrete building structures with timber structures, as well as traditional construction for prefabricated methods. A multi-storey timber residential building in Quebec City (Canada) was chosen as a baseline scenario. This building has been constructed according to the concept of green environmental protection and sustainable development. Life Cycle Assessment (LCA) approach is applied to compare the climate change impact (CC) of timber structures. In this scenario of this research, material production and construction (assembly, waste management and transportation) were assessed. Additionally, a LCA that comprises eight actions divided in four low carbon strategies, including low carbon materials, material minimization, reuse and recycle materials and adoption of local sources and use of biofuels were evaluated. The results of this study confirm the positive effect using prefabricated approach in buildings as an alternative construction method based on timber-frame-materials in Quebec. By using the CO2 emissions as global indicator, the CC saving per $m 2$ floor area in baseline scenario produces up to $25 \%$ fewer emissions than traditional buildings. If the benefits of low carbon strategies are included, the timber structures can cause up $38 \%$ lower CC than the original baseline scenario. The analysis suggests that CO2 emissions reduction in the construction of buildings as climate change mitigation is perfectly feasible by following different working lines. We concluded that the four strategies implemented have an environmental benefit in reducing greenhouse gases emissions. The reuse wood waste into production of particleboard has the greatest environmental benefit when considering temporary carbon storage.
\end{abstract}

Keywords. Timber structures, carbon reduction strategies, life cycle assessment, climate change, carbon footprint.

\footnotetext{
${ }^{\mathrm{a}}$ Corresponding author: Alejandro-de-jesus.padilla-rivera.1@ulaval.ca
} 


\section{Introduction}

The Intergovernmental Panel on Climate Change (IPCC) documents the science, impact and mitigation options of climate change. In 2010, the IPCC (Graham et al, 2014) reported that buildings accounted for $32 \%$ of total global energy use, 19\% of total Green House Gas (GHG) emissions. GHG mainly include six gases with proven global warming effects, including carbon dioxide $\left(\mathrm{CO}_{2}\right)$, methane $\left(\mathrm{CH}_{4}\right)$, nitrous oxide $\left(\mathrm{N}_{2} \mathrm{O}\right)$, hydrofluorocarbons (HFCs), perfluorocarbons (PFCs), and sulphur hexafluoride $\left(\mathrm{SF}_{6}\right)$.

In the other hand, the United Nations Environment Programme (UNEP, 2016) has declared that due to rapid urbanization and the inefficiency of existing building stock, GHG emissions will be duplicated by 2030 unless mitigation strategies are implemented, therefore, GHG emissions reductions in the building sector is an important focus of research. Consequently, reducing the energy use and climate change impacts of buildings is seen as a critical climate change mitigation measure by the IPCC (Skullestad, Bohne, and Lohne 2016).

The last decades have seen extensive efforts to increase the efficiency of buildings operation, to reduce the related energy use and GHG emissions. With the adoption low energy buildings, renewable energies and the reduction of energy consumption and GHG emissions during the use phase, the relative contribution from building materials increased. In new energyefficient buildings, the embodied energy use related to construction, transport and production of building materials and demolition can constitute, according to different authors, from $10-50 \%$ of the total life cycle energy consumption Cellura et al. 2014, Suzuki \& Oka 1998, Dixit et al. 2013).

It is important to take into consideration a wider range of impacts. In this sense, a strong analysis of the degree of energy or GHG emissions reductions is important for understanding the contributions buildings to achieve efficiency measures that can make to climate mitigation. The LCA technique provides better decisions support when optimising environmentally favourable design solutions that consider the impact cause during the entire lifetime of building (Malmqvist et al. 2011).

The LCA of buildings is rapidly developing field. While the use of LCA is not yet a standard building practice (Malmqvist et al, 2011), the method is rapidly adopted in the development of green buildings, especially those which have low GHG emissions. According to Mao et al. (2013), several studies evaluating GHG emissions with LCA approach, have been concentrated on quantifying emissions during operation and end of life stages of buildings (operating carbon), where as only a few are focus on material manufacturing, construction methods and assembly (embodied carbon). In this sense, a study performed by Dahlstrøm et al. (2012) indicated that the production phase impacts are, in most cases, lower than use phase impacts, but for some specific measures in buildings with very high energy efficiency, the trade-off can be negative. The next step in building sector is thus to minimise impacts related to the production, transport and fabrication methods of buildings.

The combination of population growth and GHG emission reduction targets stimulates construction of more densely concentrated urban areas with "nearly zero buildings" that comes with stronger structures and have fewer use of materials per floor area. Thus, choosing environmental friendly construction materials is especially important for buildings. Structural systems have traditionally consisted of steel and concrete. Production of these materials is energy emissions intensive, and accounts for a great portion of total GHG emissions from materials production in the building sector. Timber building material prove to cause considerably lower climate change impact than materials of steel and concrete.

Oka et al. (1993) quantified the energy consumption and carbon emissions produced by construction in Japan while Buchanan \& Honey (1994) has performed a detailed study on the embodied carbon of buildings and resulting $\mathrm{CO} 2$ emissions from wood, concrete, and steel structures for office and residential purposes in New Zealand and concluded that wood structures have less embodied carbon than concrete and steel structures. In Europe the quantity of greenhouse gases avoided by replacing steel with wood in buildings in Norway and Sweden is $0.06-0.88 \mathrm{~kg} \mathrm{CO}$-eq per $\mathrm{kg}$ input of timber; while replacing concrete with wood reaches $0.16-1.77 \mathrm{~kg}$ CO2-eq/kg (Petersen and Solberg 2005).

Furthermore, there is potential to reduce embodied carbon requirements using building strategies that produce less GHG emissions during manufacturing (Shadram et al, 2016). These strategies can include the use of low-carbon materials, material reuse, recycling and minimization, selection of optimal structural system and structural optimization and optimization of construction operations, such as prefabrication methods (Roh et al. 2017,Shadram et al. 2016,Yeo \& Gabbai 2011,Thomark 2000). These approaches are translated into reductions in cost, time, defects, health and safety risks, and a consequent increase in quality, predictability, whole-life performance and profitability (Jaillon \& Poon 2014, Tam et al. 2015, Cao et al. 2015).

Another aspect to take into consideration is the uptake of GHG emissions from the atmosphere during the 
photosynthesis, a unique process feature of plant biomass. The transformation of biomass (and its embodied "biogenic" carbon) into products represents in effect a removal of $\mathrm{CO}_{2}$, via its continued storage in the product over a period of time. Bio-based products can thus contribute to reduce the $\mathrm{CO}_{2}$ level in the atmosphere and address climate change. In this sense, for carbon footprint accounting purposes, biogenic carbon embodied in a product should be considered as a $\mathrm{CO}_{2}$ reduction or avoided emissions. Since this study is limited to embodied GHG emissions, it is not calculated environmental impact resulted from the biogenic $\mathrm{CO}_{2}$ circulation, the $\mathrm{CO}_{2}$ storage in the buildings for years of use.

The goal of this study is to estimate $\mathrm{CO}_{2}$ reduction strategies as climate change mitigation-measures from the building sector by considering a baseline building. Life cycle assessment is applied to assess the potential of reducing GHG emissions (embodied carbon) from heavy structures versus timber structures. In addition, a comparison of the impacts due to implementation of carbon reduction strategies, e.g. construction optimization strategies, waste reduction practices, low carbon materials substitution and local sourcing and transport minimization was performed.

To facilitate comparison and reporting, an aggregate measure, known as carbon equivalent, is usually used to quantify and report the overall global warming impact cause by various greenhouse gas emitted during a process. Throughout this paper, the term embodied carbon emissions is used to refer to carbon equivalent emissions. This cradle-to-gate study considers only embodied carbon emissions (building materials during all processes of production, on-site construction and disposal). The obtained results should enable to target the specific sources of GHG emissions in the production phase and construction phase and establish knowledge for building professionals such as engineers, architects and interior designers for developing guidelines for application in other countries and to efficient the results to final users and clients.

\section{Methods}

The key steps of the methodology are summarized below. Each of the steps outlined are described in more detail in the following sections.

\subsection{Overview}

This section describes the case study building that was analysed and the methods used to determine the GHG emissions associated with both timber and concrete construction approaches for this building.

\subsection{Life Cycle Assessment (LCA)}

This section describes the case study building that was analysed and the methods used to determine the GHG emissions associated with both timber and concrete construction approaches for this building.

LCA is a cradle to grave approach for product/service/system that evaluates the environmental effects associated with any given activity from the initial gathering of raw materials from the earth (petroleum, crops, ore, etc.) to the point at which all the materials are returned to the earth (Figure 1). This evaluation includes all side stream releases to the air, water, and soil. LCA is an attempt to comprehensively describe all these activities and the resulting environmental release and impacts. In order to carry out this research and to quantify GHG emissions, the recommendations of the ISO 14040 series (ISO, 2006) were followed. This LCA study has been modelled using Open LCA 1.5.0 software. All data are collected from the Société d'habitation du Québec (SHQ), the Province of Quebec Social Housing Agency.

Since the focus on this research is the construction of buildings, the process of manufacture, delivery and assembly of the components are included in the system. Meaning that, use and demolition and final disposal are not considered. The system boundary of this study is shown in Figure 2.

For this study, a Global Warming Potential (GWP) indicator has been evaluated based on TRACI 2.1 (EPA, 2012) that utilizes 2013 IPCC characterisation factors considering a time horizon of 100 years (IPCC, 2001).

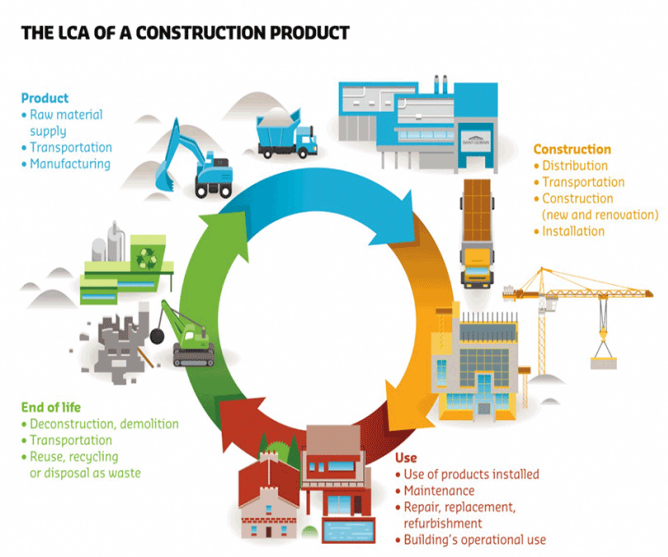

Figure 1. LCA Methodology (ISO, 2006).

\subsubsection{Functional unit}

The functional unit defined as a measure of the performance of the functional outputs of the product system. In LCA, the functional unit provides a reference to which the inputs and outputs are related. According to 
Gustavsson \& Sathre, (2011) different functional units could be use in the energy and carbon studies of buildings. These units include $1 \mathrm{~m}^{2}$ of a building's gross or usable floor area, total gross or usable floor area and the complete building. Thus, to establish a baseline to evaluate the prefabricated building and to make comparison, the functional unit for this study is defined as $1 \mathrm{~m}^{2}$ of floor area.

\subsubsection{Case study building (baseline)}

An existing multi-storey building is used as reference to model the wood-frame building system explored in this study. The building selected is part of a $93,000-\mathrm{m}^{2}$ area located on the lands of the Cité Verte, in the SaintSacrement district of Quebec City. This residential complex, consisting of condominiums, townhouses and offices and businesses, aims to integrate sustainable development elements from the design and exploitation of energy management, waste management, transportation and construction techniques.

The reference building is a mass timber structure. It is a four-story building and contains a total of 20 apartments with a total living area of $1512.3 \mathrm{~m}^{2}$ (75 $\mathrm{m}^{2}$ per unit). The multi-residential building currently biomass district heating system for its space heating and domestic hot water needs, storm water management to reduce energy use associated with water, and innovative planning to encourage alternative modes of transportation.

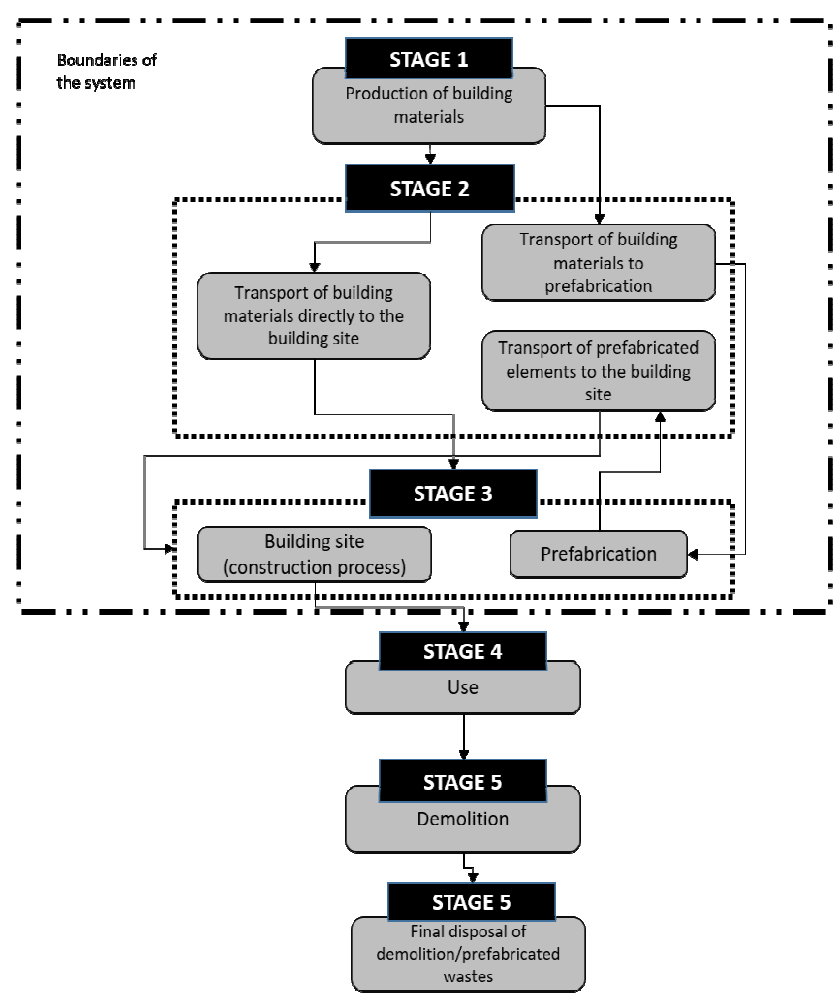

Figure 2. Systems boundaries

\subsubsection{Life Cycle Inventory}

The LCI component identifies and quantifies the material and energy resource inputs as well as the emissions and product outputs from the unit processes in accordance with the functional unit and boundaries. The LCI is an iterative process that requires time and amount of research, fortunately the use of databases help in the process. The U.S Life Cycle Inventory Database, developed by National Renewable Energy Laboratory, and Ecoinvent database, which has been developed by a Swiss initiative haven been selected as a reference in this study. All the unit processes selected in this database were cradle-to grave processes. A report from the SHQ on sustainable building has been used for the modelling this research. For the current study, Table 1 shows the main construction materials with the respective quantities and processes used for the prefabricated building construction.

Table 1. Materials and quantities used in each stage under evaluation.

\begin{tabular}{|c|c|c|}
\hline Life cycle stage & Material/process & $\begin{array}{l}\text { Quantity } \\
\left(\text { per } 1 \mathrm{~m}^{2}\right)\end{array}$ \\
\hline \multirow{19}{*}{$\begin{array}{l}\text { Material acquisition } \\
\text { and material } \\
\text { production }\end{array}$} & $\begin{array}{l}\text { Cross Laminated timber } \\
(\mathrm{CLT})\end{array}$ & $0.27 \mathrm{~m}^{3}$ \\
\hline & Glue laminated & $0.0019 \mathrm{~m}^{3}$ \\
\hline & Steel & $3.98 \mathrm{~kg}$ \\
\hline & Gypsum fibreboard & $4.92 \mathrm{~m}^{2}$ \\
\hline & Concrete & $0.15 \mathrm{~m}^{3}$ \\
\hline & Vinyl boards & $3.15 \mathrm{~kg}$ \\
\hline & Granite & $3.88 \mathrm{~kg}$ \\
\hline & Ceramic tiles & $1.83 \mathrm{~kg}$ \\
\hline & Primer & $0.499 \mathrm{~kg}$ \\
\hline & Paint & $1.35 \mathrm{~kg}$ \\
\hline & Bricks & $50.23 \mathrm{~kg}$ \\
\hline & Windows & $0.03 \mathrm{~m}^{2}$ \\
\hline & Metal doors & $0.06 \mathrm{~m}^{2}$ \\
\hline & Wooden doors & $0.30 \mathrm{~m}^{2}$ \\
\hline & Fiberglas & $1.72 \mathrm{~kg}$ \\
\hline & Spray polyurethane & $0.06 \mathrm{~kg}$ \\
\hline & Elastomeric membrane & $0.28 \mathrm{~kg}$ \\
\hline & $\begin{array}{c}\text { Coverage bitumen } \\
\text { membrane }\end{array}$ & $0.08 \mathrm{~kg}$ \\
\hline & $\begin{array}{c}\text { Transportation to site } \\
\text { assemblya }\end{array}$ & $\begin{array}{l}188.81 \mathrm{t}- \\
\mathrm{km}\end{array}$ \\
\hline \multirow[t]{4}{*}{ Assembly } & Electricity & $85.65 \mathrm{kwh}$ \\
\hline & Excavation & $0.0264 \mathrm{~m}^{3}$ \\
\hline & Diesel & $0.9919 \mathrm{kwh}$ \\
\hline & Transportation to site & $27.9 \mathrm{t}-\mathrm{km}$ \\
\hline
\end{tabular}




\begin{tabular}{|c|c|}
\hline construction (100km) & \\
\hline $\begin{array}{c}\text { Waste Managementb } \\
\text { (WM) (wood) }\end{array}$ & $9.91 \mathrm{~kg}$ \\
\hline WM (gypsum) & $5.26 \mathrm{~kg}$ \\
\hline WM (Iron metals) & $6.11 \mathrm{~kg}$ \\
\hline WM (plastic) & $0.1656 \mathrm{~kg}$ \\
\hline WM (carton/paper) & $3.83 \mathrm{~kg}$ \\
\hline WM (insulation wool) & $0.4228 \mathrm{~kg}$ \\
\hline WM (Polythene) & $3.46 \mathrm{~kg}$ \\
\hline $\begin{array}{c}\text { WM Transportation }(25 \\
\text { km) }\end{array}$ & $\begin{array}{c}0.6298 \mathrm{t}- \\
\mathrm{km}\end{array}$ \\
\hline
\end{tabular}

\subsection{Description of carbon reduction strategies}

In order to investigate the sensitivity of embodied carbon emissions from this building, design configuration was changed through a hypothetical way. Four hotspots approaches were defined in line with the commonly carbon reduction strategies. They were conducted to single out those having the greatest potential for reducing environmental impact in baseline scenario. These strategies are divided and described into the following categories: 1) low carbon materials, 2) material minimization, 3) reuse and recycling strategies and 4) local sourcing and transport minimization.

\section{Results}

\subsection{Global warming potential of baseline scenario}

The total CO2-e. emissions are presented as the Global Warming Potential (GWP) per $1 \mathrm{~m}^{2}$ of floor area. The estimated carbon footprint of the building material manufacturing phase and construction process was 275 $\mathrm{kg} \mathrm{CO}$-e. $/ \mathrm{m}^{2}$. Compared to authors' previous study of different frames/construction methods, whose system boundary is almost the same as in this study. It shows that embodied $\mathrm{CO} 2$-e emissions of building per functional unit of reference $\left(1 \mathrm{~m}^{2}\right)$ of base case is fewer (35 to $672 \mathrm{~kg} \mathrm{CO}_{2}$-e) than $66 \%$ of literature analysed, but 33\% higher (183 and $205 \mathrm{~kg} \mathrm{CO}_{2}$-e) than references in Table 2. This gap is because almost all buildings materials in building \#2 and \#3 use lower carbon materials, such as wood products, and the use of concrete and steel, principal $\mathrm{CO}_{2}$-e emitters are limited. The transportation energy during fabrication/construction also contributes to reduce $\mathrm{CO}_{2}{ }^{-}$ e emissions.

The embodied carbon difference by case base and reference buildings 3 to 9 is attributed principally to modular construction technic, light frame materials and low energy during assembly process. As it can be seen the base case showed an average decrease about $150 \%$ $\mathrm{CO} 2$-e emissions, this was achieved for the use of wood as a low-carbon construction material than conventional concrete and steel in the case building considered, highlighting the importance of material selection in reducing the overall carbon footprint in Canada. These results agrees with (Nässén et al. 2012) who indicate that, in New Zeeland, increasing the use of wood around $15 \%$ may result in a $20 \%$ reduction in carbon emissions due to the manufacturing construction materials, thus, about a $1.5 \%$ reduction in the country's total carbon emissions.

It should be noted that the results in Table 2 make an interesting reading. It turns out that bigger constructed areas produce more carbon dioxide per $\mathrm{m} 2$ than small ones. That may come as a surprise, given that there are so many economies of scale at work in bigger constructions, however Fragkias et al. (2013) emphasizes the importance of size as a major factor in determining the intensity of $\mathrm{CO}_{2}$-e emissions, although large urban areas are more innovative than smaller ones, they may lack capacity in steering eco-innovations towards their local markets for fossil fuels. These important hypotheses remain untested and need to be addressed in future research.

Furthermore, the selection of modular/semiprefabrication method over conventional construction suggests that the emissions of prefabricated wood-frames technology may result in lowest life cycle carbon footprint, attributed to the higher level of prefabrication of the base case under study, that according to (Pons, 2014) a higher degree of prefabrication could contribute to greater benefits on environmental impact, such as GHG emissions.

Table 2 Comparison of embodied carbon among different literatures

\begin{tabular}{|c|c|c|}
\hline Author & Name/Reference & $\mathrm{Kg} \mathrm{CO}_{2}$ emissions \\
\hline $\begin{array}{c}\text { Current project } \\
\text { Paya-Marin et al. } \\
\text { (2013) }\end{array}$ & $\begin{array}{c}\text { Base case } \\
\text { Quebec, Canada) }\end{array}$ & Building \#1 (UK) \\
\hline Kim 2008 & 92 & Building \#2 (USA) \\
\hline $\begin{array}{c}\text { (González and } \\
\text { García Navarro } \\
\text { 2006) }\end{array}$ & 196 & $\begin{array}{c}\text { Building \#3 } \\
\text { (Spain) }\end{array}$ \\
\hline $\begin{array}{c}\text { (Oriol Pons and } \\
\text { Wadel 2011) }\end{array}$ & 310 & $\begin{array}{c}\text { Building \#4 } \\
\text { (Spain) }\end{array}$ \\
\hline $\begin{array}{c}\text { (Mao et al. 2013) } \\
\text { (China) }\end{array}$ \\
\hline (Roh et al. 2017) & 436 & $\begin{array}{c}\text { Building \#6 } \\
\text { (Korea) }\end{array}$ \\
\hline (Aye, et al. 2012) & 578 & $\begin{array}{c}\text { Building \#7 } \\
\text { (Australia) }\end{array}$ \\
\hline $\begin{array}{c}\text { (Suzuki and Oka } \\
\text { 1998) }\end{array}$ & 790 & $\begin{array}{c}\text { Building \#8 } \\
\text { (Japan) }\end{array}$ \\
\hline $\begin{array}{c}\text { (Su and Zhang } \\
\text { 2016) }\end{array}$ & 947 & $\begin{array}{c}\text { Building \#9 } \\
\text { (China) }\end{array}$ \\
\hline
\end{tabular}




\subsection{Baseline scenario vs different buildings frame materials}

The raw material extraction, material production, including transportation account for $243 \mathrm{~kg} \mathrm{CO}$ eq. ( $88 \%$ of the total). The assembly, that includes the modular fabrication, and construction waste management is $32 \mathrm{~kg}$ de $\mathrm{CO} 2(12 \%)$. If we see the contribution from the all the sub-process in the two life cycle stages, the fabrication of materials is responsible for $75 \%$ of total GWP, transportation to site construction $13 \%$, waste management $11 \%$ while the excavation, electricity and diesel accounts only for $1 \%$.

These results are in line with other similar studies in Canada. Canadian Wood Council (CWC) (2010) and Société d'habitation du Québec (SHQ) (2016) that conducted life cycle analysis of environmental impacts of wood frame, steel and concrete buildings in Quebec. The embodied carbon footprint, materials production and assembly phases have of different buildings are shown in Figure 3 .

Findings suggest that the emissions of fabrication materials is the principal contributor to total GHG emissions in the five buildings, following by assembly phase. According to the results, the wood frames causes lower carbon emissions than concrete and steel frames. The baseline building presents significantly lower embodied CO2-e emissions $\left(275 \mathrm{~kg} / \mathrm{m}^{2}\right)$ compared to the wood frame $1\left(302 \mathrm{~kg} / \mathrm{m}^{2}\right)$ and wood frame 2 (287 $\left.\mathrm{kg} / \mathrm{m}^{2}\right)$, while concrete frame $\left(442 \mathrm{~kg} / \mathrm{m}^{2}\right)$ and steel frame $\left(353 \mathrm{~kg} / \mathrm{m}^{2}\right)$ are the greatest carbon contributors.

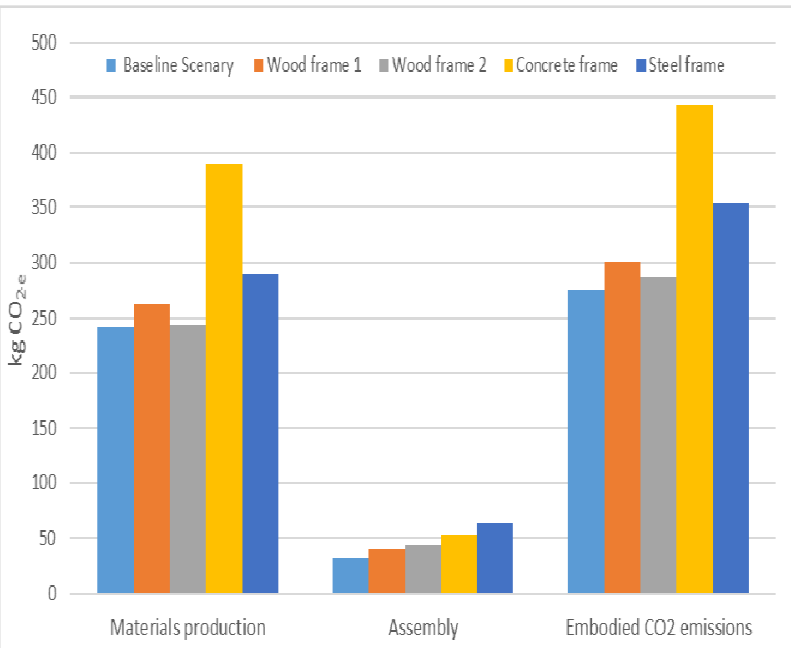

Figure 3 . Total GHG emissions of baseline scenario vs different buildings $\left(\mathrm{kg} \mathrm{CO}_{2} \mathrm{eq} / \mathrm{m}^{2}\right)$

\subsection{Implementation of carbon reduction strategies}

One of the most important skills required for the implementation of sustainable strategies in practice is the ability to evaluate the effectiveness of such strategies in the context of a real building. Quantifying the embodied carbon reductions achievable by the adoption of different low carbon reduction strategies provide keys insight into the design of low-climate-change buildings. This section combines the results of this study (baseline scenario) and the implementation analysis of factors influencing carbon emissions by mainly considering four strategies (Section 2.3).

The results of carbon reduction strategies show that overall reductions of life cycle GHG emissions are 106.5 $\mathrm{kg} \mathrm{CO} 2$-e $/ \mathrm{m}^{2}(38.8 \%)$. Figure 7 shows the breakdown in terms of life cycle stages and carbon strategies wherein the implementation of recycled of wood waste (waste management) that accounted for the largest share $-11 \mathrm{~kg}$ CO2-e $/ \mathrm{m} 2(14.6 \%)$ of the total GHG emissions have been considered to be the main hotspot. The local sourcing of materials and components (transportation) also reduce significant portion of GHG emissions $32 \mathrm{~kg}$ $\mathrm{CO}_{2}$-e $/ \mathrm{m}^{2}(11.7 \%)$. In the production of building materials $\left(178.2 \mathrm{~kg} \mathrm{CO}-\mathrm{e} / \mathrm{m}^{2}\right)$, the use of clinker materials to produce cement $(3.8 \%)$ and light clay bricks (3.6\%) have been found to be the low carbon materials actions. All other actions such as cork flooring system, reduction of waste ratios, cellulose insulation and use of biofuels together contributed to the remaining reduction of GHG emissions $13.6 \mathrm{~kg} \mathrm{CO}_{2}$-e $/ \mathrm{m}^{2}(5 \%)$.

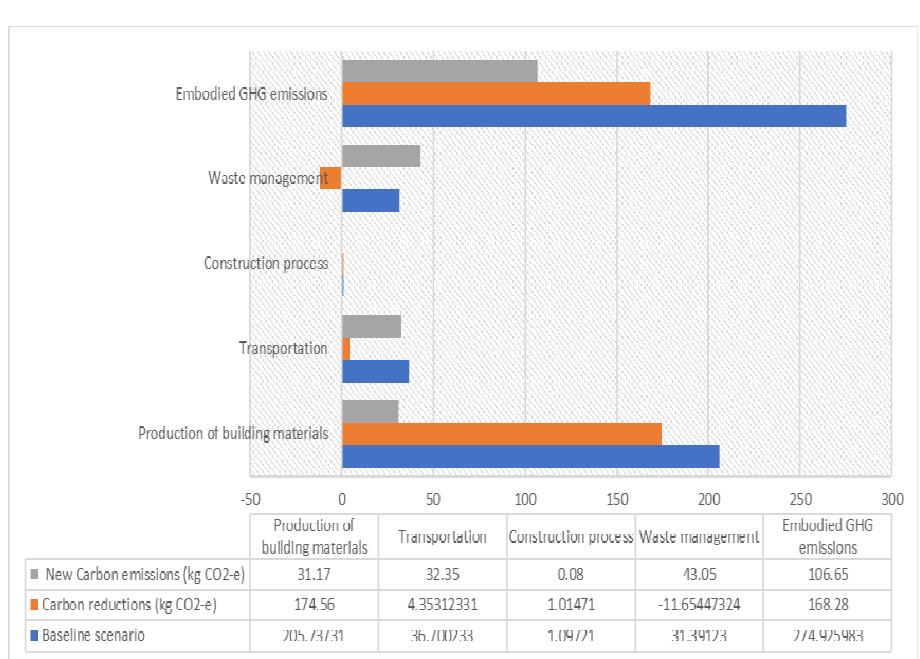

Figure 4 GHG emissions of baseline scenario, carbon reduction strategies and new carbon emissions $\left(\mathrm{kg} \mathrm{CO}_{2}-\right.$ e)

\section{Conclusions}

The results of this study confirm the positive effect using prefabricated approach in buildings as an alternative construction method based on wood-frame-materials in Quebec. According to the obtained environmental impacts, these conclusions can be drawn as follows:

-By using the $\mathrm{CO}_{2}$ emissions as global indicator, the $\mathrm{CC}$ saving per $\mathrm{m}^{2}$ floor area in baseline scenario produces up to $25 \%$ fewer emissions than traditional buildings built with steel or concrete. 
-During the life-cycle of baseline scenario, total embodied carbon emissions of $275 \mathrm{~kg} \mathrm{CO}$-e was calculated. The fabrication of building material phase contributed the most $(75 \%)$ to the carbon emissions, while transportation $(13 \%)$, construction (1\%) and waste management $(11 \%)$ contribute to $25 \%$.

-The four strategies implemented have an environmental benefit in reducing greenhouse gases emissions. The analysis of low carbon strategies showed an overall carbon reduction approximately $104 \mathrm{~kg} \quad \mathrm{CO}_{2}$-e $\quad(38 \%)$ in comparison to baseline scenario.

The $\mathrm{CO}_{2}$ emissions reduction in the construction of buildings as climate change mitigation is perfectly feasible by following different working lines. The four strategies implemented have an environmental benefit in reducing greenhouse gases emissions.

It was demonstrated that use of wood-based building materials can contribute to a sustainable built environment based on resource-efficient systems with low environmental impact. Wood building products from sustainably managed forests are a renewable resource that can provide multiple benefits during their life cycle.

Reuse of construction materials can lead to significant resource savings together with other environmental benefits from a reduction in waste disposed of in landfill and the energy required for the production of virgin materials.

\section{References}

Aye, Lu et al. 2012. "Life Cycle Greenhouse Gas Emissions and Energy Analysis of Prefabricated Reusable Building Modules." Energy and Buildings 47(APRIL 2012): 15968. http://dx.doi.org/10.1016/j.enbuild.2011.11.049 (February 2, 2016).

Buchanan, Andrew H., and Brian G. Honey. 1994. "Energy and Carbon Dioxide Implications of Building Construction." Energy and Buildings 20(3): 205-17. http://linkinghub.elsevier.com/retrieve/pii/03787788949 00248 (April 6, 2017).

Canadian Wood Council (CWC). 2010. Sustainability and Life Cycle Analysis for Residential Buildings. Quebec.

Cao, Xinying, Xiaodong Li, Yimin Zhu, and Zhihui Zhang. 2015. "A Comparative Study of Environmental Performance between Prefabricated and Traditional Residential Buildings in China." Journal of Cleaner Production 109: 131-43. http://www.sciencedirect.com/science/article/pii/S09596 52615004953 (December 28, 2015).

Cellura, Maurizio, Francesco Guarino, Sonia Longo, and Marina Mistretta. 2014. "Energy Life-Cycle Approach in Net Zero Energy Buildings Balance: Operation and Embodied Energy of an Italian Case Study." Energy and Buildings 72: 371-81.

http://www.sciencedirect.com.acces.bibl.ulaval.ca/scienc e/article/pii/S0378778813008633 (May 25, 2017).

Dahlstrøm, Oddbjørn, Kari Sørnes, Silje Tveit Eriksen, and Edgar G. Hertwich. 2012. "Life Cycle Assessment of a
Single-Family Residence Built to Either Conventionalor Passive House Standard." Energy and Buildings 54: 470-79.

http://www.sciencedirect.com.acces.bibl.ulaval.ca/scienc e/article/pii/S037877881200374X (May 25, 2017).

Dixit, Manish K., Charles H. Culp, and Jose L. FernándezSolís. 2013. "System Boundary for Embodied Energy in Buildings: A Conceptual Model for Definition." Renewable and Sustainable Energy Reviews 21: 153-64. http://www.sciencedirect.com.acces.bibl.ulaval.ca/scienc e/article/pii/S1364032112007423 (April 6, 2017).

Environmental Protection Agency, (EPA). 2012. "Tool for the Reduction and Assessment of Chemical and Other Environmental Impacts (TRACI) TRACI Version 2.1 User's Guide."

Fragkias, Michail, José Lobo, Deborah Strumsky, and Karen C Seto. 2013. "Does Size Matter? Scaling of CO2 Emissions and U.S. Urban Areas." PLOS ONE 8(6). http://journals.plos.org/plosone/article/file?id=10.1371/j ournal.pone.0064727\&type=printable (April 28, 2017).

González, María Jesús, and Justo García Navarro. 2006.

"Assessment of the Decrease of CO2 Emissions in the Construction Field through the Selection of Materials: Practical Case Study of Three Houses of Low Environmental Impact." Building and Environment 41(7): 902-9.

http://www.sciencedirect.com.acces.bibl.ulaval.ca/scienc e/article/pii/S036013230500140X?np=y\&npKey $=$ f8826 688e172ec7050e0daf4821f4c94c2cc0b149c5a83b29c9e 8 ff57ccc3e80 (October 11, 2016).

Graham, Peter et al. 2014. Buildings. In: Climate Change 2014: Mitigation of Climate Change. Contribution of Working Group III to the Fifth Assessment Report of the Intergovernmental Panel on Climate Change. Cambridge, United Kingdom and New York, NY, USA: Volker Krey.

Gustavsson, Leif, and Roger Sathre. 2011. "Energy and CO2 Analysis of Wood Substitution in Construction." Climatic Change 105(1-2): 129-53. http://link.springer.com/10.1007/s10584-010-9876-8 (September 29, 2016).

International Organization for Standardization (ISO). 2006. ISO 14040:2006 - Environmental Management -- Life Cycle Assessment -- Principles and Framework. http://www.iso.org/iso/catalogue_detail?csnumber $=3745$ 6.

IPCC (Intergovernmental Panel on Climate Change). 2001. CLIMATE CHANGE 2001: THE SCIENTIFIC BASIS. Cambridge, U.K. .

Jaillon, Lara, and C.S. Poon. 2014. "Life Cycle Design and Prefabrication in Buildings: A Review and Case Studies in Hong Kong." Automation in Construction 39: 195 202.

Malmqvist, Tove et al. 2011. "Life Cycle Assessment in Buildings: The ENSLIC Simplified Method and Guidelines." Energy 36(4): 1900-1907. http://www.sciencedirect.com.acces.bibl.ulaval.ca/scienc e/article/pii/S0360544210001453 (May 25, 2017).

Mao, Chao, Qiping Shen, Liyin Shen, and Liyaning Tang. 2013. "Comparative Study of Greenhouse Gas Emissions between off-Site Prefabrication and Conventional Construction Methods: Two Case Studies of Residential Projects." Energy and Buildings 66: 16576. http://dx.doi.org/10.1016/j.enbuild.2013.07.033 (October 27, 2016).

Nässén, Jonas, Fredrik Hedenus, Sten Karlsson, and John Holmberg. 2012. "Concrete vs. Wood in Buildings - An Energy System Approach." Building and Environment 51: 361-69. 
http://dx.doi.org/10.1016/j.buildenv.2011.11.011 (April 26, 2017).

Oka, Tatsuo, Michiya Suzuki, and Tetsuo Konnya. 1993. "The Estimation of Energy Consumption and Amount of Pollutants due to the Construction of Buildings." Energy and Buildings 19(4): 303-11. http://linkinghub.elsevier.com/retrieve/pii/03787788939 0016N (April 6, 2017).

Paya-Marin, M.A., J. Lim, and B. Sengupta. 2013. "Life-Cycle Energy Analysis of a Modular/Off-Site Building School." American Journal of Civil Engineering and Architecture 1(3): 59-63. http://pubs.sciepub.com/ajcea/1/3/2/index.html\#.UbmM o8r9U10

Petersen, Ann Kristin, and Birger Solberg. 2005.

"Environmental and Economic Impacts of Substitution between Wood Products and Alternative Materials: A Review of Micro-Level Analyses from Norway and Sweden." Forest Policy and Economics 7(3): 249-59. http://linkinghub.elsevier.com/retrieve/pii/S1389934103 000637 (October 26, 2016).

Pons, O. 2014. Eco-efficient Construction and Building Materials Eco-Efficient Construction and Building Materials. Elsevier.

http://www.sciencedirect.com/science/article/pii/B97808 57097675500182 (January 27, 2016).

Pons, Oriol, and Gerardo Wadel. 2011. "Environmental Impacts of Prefabricated School Buildings in Catalonia." Habitat International 35(4): 553-63. http://dx.doi.org/10.1016/j.habitatint.2011.03.005.

Roh, Seungjun, Sungho Tae, Sung Joon Suk, and George Ford. 2017. "Evaluating the Embodied Environmental Impacts of Major Building Tasks and Materials of Apartment Buildings in Korea." Renewable and Sustainable Energy Reviews 73(December 2016): 135-44.

http://www.sciencedirect.com.acces.bibl.ulaval.ca/scienc e/article/pii/S1364032117300916 (April 6, 2017).

Shadram, Farshid et al. 2016. "An Integrated BIM-Based Framework for Minimizing Embodied Energy during Building Design." Energy and Buildings 128: 592-604. http://www.sciencedirect.com.acces.bibl.ulaval.ca/scienc e/article/pii/S0378778816306041 (April 6, 2017).

Skullestad, Julie Lyslo, Rolf André Bohne, and Jardar Lohne. 2016. "High-Rise Timber Buildings as a Climate Change Mitigation Measure - A Comparative LCA of Structural System Alternatives." Energy Procedia 96: 112-23. http://linkinghub.elsevier.com/retrieve/pii/S1876610216 307512 (May 25, 2017).

Société d'habitation du Québec (SHQ). 2016. Life Cycle Assessment of Residencial Buildings. Quebec.

$\mathrm{Su}$, Xing, and Xu Zhang. 2016. "A Detailed Analysis of the Embodied Energy and Carbon Emissions of SteelConstruction Residential Buildings in China." Energy and Buildings 119: 323-30. http://dx.doi.org/10.1016/j.enbuild.2016.03.070.

Suzuki, Michiya, and Tatsuo Oka. 1998. "Estimation of Life Cycle Energy Consumption and CO2 Emission of Office Buildings in Japan." Energy and Buildings 28(1): 33-41. http://linkinghub.elsevier.com/retrieve/pii/S0378778898 000103 (April 6, 2017).

Tam, Vivian W.Y., Ivan W.H. Fung, Michael C.P. Sing, and Stephen O. Ogunlana. 2015. "Best Practice of Prefabrication Implementation in the Hong Kong Public and Private Sectors." Journal of Cleaner Production 109: 216-31.

Thomark, C. 2000. "Environmental Analysis of a Building with Reused Building Materials." International Journal of Low Energy and Sustainable Buildings 1. http://dspace.mah.se/bitstream/handle/2043/9844/staffan storp.pdf?sequence $=1$ (April 7, 2017).

UNEP. 2016. The Emissions Gap Report 2016. The Emissions Gap Report 2016. United Nations Environment Programme (UNEP). Nairobi. file://C:/Users/ADPAR12/Downloads/emission_gap_re port_2016.pdf (April 5, 2017).

Yeo, DongHun, and Rene D. Gabbai. 2011. "Sustainable Design of Reinforced Concrete Structures through Embodied Energy Optimization." Energy and Buildings 43(8): 2028-33.

http://www.sciencedirect.com.acces.bibl.ulaval.ca/scienc e/article/pii/S0378778811001678 (April 6, 2017). 